a Detroit creamery. He wanted to go to school but he had to support his family. It was a struggle. . . "' Dr. Solomon's 209-page thesis was entitled "The Negro in Detroit Elections."

When Thomas R. Solomon received the Doctor of Philosophy in political science in 1939, he became only the second black American to receive the terminal degree in the field. The first was Ralph Bunche, Nobel Prize laureate and American Political Science Association president. While he could earn a salary at the Post Office equivalent to that available at a black college, he was committed to a career in higher education. Dr. Solomon joined the Prairie View faculty in 1939 and remained at the university until his retirement in 1972. During his tenure, he served as professor of history, political science and philosophy; registrar; football coach; dean of students; and campus coordinator for many programs. Among his most outstanding positions was chief of party for the university's contract with the International Cooperation Administration's Point 4 Program of economic and educational assistance to Liberia from 1955 to 1958 . In 1961, the Liberian government conferred upon him the award "Knight Commander of the Humane Order of African Redemption" in recognition of the work done there, especially the establishment of the Booker T. Washington Technical Institute in Kakata, an institution which greatly expanded opportunity for advanced technical vocational training in that nation.

A master teacher and scholar, Dr. Solomon taught major courses in political science and served as consultant to university officials, government agencies and community institutions and groups. Under his leadership the undergraduate program in political science was developed at Prairie View. Among his former students at Prairie View are several professors of political science at colleges and universities across the nation, as well as successful lawyers. Former political science faculty members at Prairie View found in Dr. Solomon a strong mentor and career development facilitator.

Professor Solomon served as a member of the City Council of the City of Prairie View. Early in his tenure at Prairie View he was active in voter registration drives and the effort to get a voting precinct in the university community. He also played a major role in getting Prairie View incorporated as a municipality.

A man of indefatigable energy he held leadership roles in religious, civic, educational and political organizations. Following the death of his first wife, Lottie Green, Dr. Solomon married Pearl E. Foreman, who died in 1985 . He is survived by two sons, Samuel of Phoenix, Arizona, and James of Detroit, Michigan; 14 grandchildren, and many relatives and friends. A son, Thomas R. Solomon, Jr., preceded him in death.

Jewel L. Prestage

Prairie View A\&M University

\section{Jean G. Walen}

Jean G. Walen, who served in a range of administrative positions at the American Political Science Association from 1957 to 1991 when illness caused her retirement, died at her home in Rockville, Maryland, on November 5, 1992. Jean was born in Dufer, Oregon, and was a graduate of the University of Oregon. Before moving to Washington in 1955 , she was a reporter for the Eugene [Ore.] Register-Guard for two years. She is survived by her son, Michael, her mother, Annie Godknecht, and two sisters.

At the association, Jean worked with great dedication and skill on many programs and activities, including the Congressional Fellowship Program, annual meeting program coordination, the public affairs reporting awards, the annual dissertation list compilation, professional programs to enhance AfricanAmerican participation in the profession, professional awards, association directories, nominating committees, and she was administrative assistant to two executive directors, Evron M. Kirkpatrick and Thomas E. Mann. She also worked on projects that gave her special enjoyment, such as collecting material on former association presidents, assisting in the development of the Pendleton Herring collection of political art at the association headquarters, and compiling and publishing in $P S$ the list of the association's long-time members by years of membership.

At the memorial service for Jean, messages were read from a number of distinguished association members, including Pendleton Herring, Charles $\mathrm{O}$. Jones, Ruth Jones and Warren Miller, Jack Peltason, Nelson W. Polsby, Lucian W. Pye, and Austin Ranney. These communications attested to her long and excellent service and the view that Jean had served as the institutional memory of the association, which helped it to grow and to maintain the loyalty, respect, and support of its members.

Jean Walen was an institution builder, and the American Political Science Association is stronger for her work and life.

Walter E. Beach

Helen Dwight Reid Educational. Foundation 